\title{
Indirect field technology for detecting areas object of illegal spills harmful to human health: application of drones, photogrammetry and hydrological models
}

\author{
Alessandra Capolupo ${ }^{1}$, Stefania Pindozzi ${ }^{1}$, Collins Okello², Lorenzo Boccia ${ }^{1}$ \\ ${ }^{1}$ University of Naples Federico II, Department of Agricultural Sciences, Portici, Italy; ${ }^{2}$ Gulu University, \\ Department of Biosystems Engineering, Gulu, Uganda
}

\begin{abstract}
The accumulation of heavy metals in agricultural soils is a serious environmental problem. The Campania region in southern Italy has higher levels of cancer risk, presumably due to the accumulation of geogenic and anthropogenic soil pollutants, some of which have been incorporated into organic matter. The aim of this study was to introduce and test an innovative, field-applicable methodology to detect heavy metal accumulation using drone-based photogrammetry and microrill network modelling, specifically to generate wetlands wetlands prediction indices normally applied at large catchment scales, such as a large geographic basin. The processing of aerial photos taken using a hexacopter equipped with fifth-generation software for photogrammetry allowed the generation of a digital elevation model (DEM) with a resolution as high as $30 \mathrm{~mm}$. Not only this provided a high potential for the study of micro-rill processes, but it was also useful for testing and comparing the capability of the topographic index $(T I)$ and the clima-topographic index $(C T I)$ to predict heavy metal sedimentation points at scales from 0.1 to 10 ha. Our results indicate that the TI and CTI indices can be used to predict points of heavy metal accumulation for small field catchments.
\end{abstract}

Keywords: photogrammetry, drones, topographic index, heavy metals soil pollution, health, Italy.

\section{Introduction}

The accumulation of heavy metals in agricultural soils is one of the currently most critical environmental problems, as these soil contaminations are absorbed by crops and ultimately affect food quality. It is important to know the concentrations of heavy metals in soil, since excessive accumulation causes serious health problems (Oliver, 1997; Muchuweti et al., 2006) of various kinds, particularly neurotoxicity, carcinogenicity and mutagenicity (European Union, 2002). For example, arsenic (As), mercury (Hg), zinc $(\mathrm{Zn})$, copper $(\mathrm{Cu})$ and aluminium $(\mathrm{Al})$ affect the gastrointestinal system, generally resulting in diarrhoea and vomiting; at higher levels, these compounds cause systemic effects, such as depression tremor, ataxia, convulsions, paralysis, or pneumonia (McCluggage, 1991); Cadmium (Cd) is a potential carcinogen, commonly associated with symptoms from the cardiovascular, urinary and nervous systems (Jarup, 2003); lead

\footnotetext{
Corresponding author:

Lorenzo Boccia

University of Naples Federico II

Department of Agriculture

Via Università 100, 80055 Portici, Naples, Italy

Tel. +39081 253-9151

E-mail: lorenzo.boccia@unina.it
}

$(\mathrm{Pb})$ and $\mathrm{Cd}$ may decrease human life expectancy up to 10 years (Lăcătuşu et al., 1996).

The Italian situation with regard to soil contamination is extremely heterogeneous and complex. As many as 55 environmental sites of national interest (SIN) have been identified; six of them situated in the Campania region in southern Italy (Vito et al., 2009). These Campania areas are also among the 44 places listed by the National Institute of Health due to high levels of cancer risk correlated with high soil concentrations of heavy metals resulting from a combination of geogenic and anthropogenic pollution (Cicchella et al., 2005). Geogenic pollution is mainly linked to natural phenomena, such as volcanic activities and related hot springs and fumaroles (De Vivo, 1995), while anthropogenic pollution essentially has to do with industrial activity. The voluntary or accidental pollution of the latter has produced high concentrations of $\mathrm{Cd}$, chromium $(\mathrm{Cr}), \mathrm{Cu}, \mathrm{Hg}, \mathrm{Pb}$, nickel $(\mathrm{Ni})$ and $\mathrm{Zn}$ (Filippelli et al., 2012). High concentrations of most of these metals, as well as selenium (Se), can also be found along the road system, where they constitute pollution from motorized traffic (Albanese et al., 2012), while the use of inorganic pesticides and chemical fertilizers produce high concentrations of $\mathrm{Cu}, \mathrm{Hg}$, $\mathrm{Mn}, \mathrm{Pb}$ and $\mathrm{Zn}$ in the fields used for agriculture (Swaine et al., 1962). Soil pollution includes also point sources like gasoline pumps and places where house- 
hold waste has been dumped illegally (De Vivo et al., 2012). Although the geogenic contaminants in the Campania region are known and/or are foreseeable (Albanese et al., 2007), it is still difficult to map and predict the extent and location of anthropogenic pollutants, mainly because of patchy occurrence and uneven diffusion.

Current procedures for pollution mapping are laborious and expensive, since they involve the analysis of a large set of organic and inorganic substances in each homogeneous soil unit. Soil investigation is typically carried out using a grid with a realtively dense mesh $(10 \times 10 \mathrm{~m})$, making it hard to sample and examine large areas. When located between the source of pollution and a receiving water body, certain landscape structures act as physical or biogeochemical barriers against contaminants (Muscott et al., 1993) as well as infections (De Roeck et al., 2014). Due to absorption of pollutants by plants and dilution in the absence of significant nitrogen concentration and denitrification processes (Montreiul et al., 2008), wetlands have been classified as area buffers. The detection of minor spots of pollution due to illegal spills is the main problem, as the approach used for wetlands prediction at the basin scale need to be adapted for detection of "hotspots" at the micro-catchment scale.

In order to describe surface morphology and understand the processes that characterize the environment, it is necessary to collect a large number of data across a wide range of Earth sciences, e.g. geology (Gold et al., 1973), hydrology (Hooke et al., 1994) and hill slope geomorphology (Evans, 1977). Land-forms are commonly characterised by digital elevation models (DEM) (Florinsky, 1998) that produce essential baseline information for morphometric analysis. However, it is important to emphasize that land-form results depend on the accuracy with which DEM is measured. In fact, the detection of geomorphic elements depends critically on the input data used, taking into account how they are influenced by DEM accuracy, i.e. the higher the resolution, the better the land-form reconstruction. Landscape representation depends strongly on DEM resolution: land-form elements can assume different values at the same location when the resolution varies (Dặgut and Eisank, 2011). Therefore, more studies are necessary to understand and explain the relationship between scale and geomorphometric analysis.

An assessment of the efficiency of different topographical and hydrological indices suited to predict wetlands at large catchment scales, e.g. a large land basin, has been done by Infascelli et al. (2013), who established the ordinate climate-topographic index (OCTI) for this work. It is likely that these indices can be applied at smaller scales, such as small-field catchments, but in this context, they must be calculated based on highly accurate land-form mapping. Dehn et al. (2001) listed different definitions for this purpose, while Minár and Evans (2008) propose that the main objective of this type of mapping is the identification of specific, geometrical geomorphic elements with maximal potential influence on the processes studied. The most important attributes to contour or surface topography units are: elevation, slope, aspect, plane, profile curvature and flow accumulation (Moore et al., 1993). Previously, land-form mapping was typically done by visually interpreting aerial photographs (Dent and Young, 1981), but can now be done digitally thanks to fast computers and introduction of the fifthgeneration software for photogrammetry (Mulder et al., 2010). This software can lead to a significant reduction in photo processing time because of its capacity to deal with hundreds of photographs and automatic restitution at the same time (PierrotDeseilligny et al., 2011).

The introduction of drone photography, another important innovation, may significantly improve results as it permits further reduction of time and cost of data acquisition. Indeed, drones could facilitate the entire operation of monitoring flight due to the possibility of quota reduction and reaching difficult-toaccess areas (Nex et al., 2013). Drones also make it possible to obtain aerial photos at scales ranging from 0.1 to 10 ha, a high-resolution approach resulting in a considerable increase of DEM accuracy. However, it is important that the resolution is suited to the object under investigation (Evans, 2012). Lejot et al. (2007) realized early the high potential of DEM generated by drone-based photogrammetry when investigating hydrologic networks, channel featurees, water depth, etc., while Bishop et al. (2011) used geomorphic data and simple laws of hydrology to analyse drainage basins, in order to create realistic simulation of river channels, sediment transport and their storage. Following these findings, Hugenholtz et al. (2013) demonstrated that the DEM accuracy resulting from overlapping drone images obtained by photogrammetry is appropriate for geomorphologic studies.

In the present study, a highly innovative methodology for the prediction of heavy metal spills at small scales (spot presence) was attempted. It is based on an "inverse" approach to detect the distribution of sedimentation points and specifically aimed at identifying the points to be sampled. The goal was to direct sam- 
pling by involving transport modelling and new procedures for predicting the distribution of wetlands in catchments areas at limited scales to find accumulations of heavy metals assimilated into sedimentation zones similar to wetlands.

It is essential to detect the hydrological network for specification of transport pathways in a catchment, in order to understand the relationship between diffsion of heavy metals and their accumulation points (Ollesch et al., 2006). Areas with accumulated contaminants such as wetlands can be seen as sedimentation micro-basins. This work presumed that indices suited to predict wetlands at small scales, such as the topographic index (TI) and the clima-topographic index $(C T I)$, can also be used to detect accumulation of heavy metals in agricultural soil. However, in order for indices to be transferred to this more limited scale, they must be subjected to extremely accurate considerations consisting of the following phases:

(i) land-form mapping;

(ii) modelling of transport process;

(iii) calculation of indices suited to predict wetlands distribution; and

(iv) detection of areas characterized by potential heavy metal accumulation that would reveal the presence of illegal spills.

\section{Material and methods}

\section{Study area}

The municipality of Trentola Ducenta, Caserta Province in the Campania region in southern Italy is one of 77 communes in the Domizio-Flegreo Littoral and Agro Aversano areas given SIN status. The experiment recorded here was performed in an area measuring $4,500 \mathrm{~m}^{2}$, where a patchy occurence of pollution of heavy metals and organic contaminants was expected.

\section{Land-form mapping}

To increase the DEM resolution of the area of interest, a survey with the use of a drone (Fig. 1) was planned. The drone configuration must be optimized according to the frame and load to be lifted and, although the quadricopter is the "gold standard", we preferred using a hexacopter due to its greater stability and lift power. The Tarot FY690s hexacopter frame (Aereomodellistica S.r.l. Moricone, RM, Italy http://www.jonathan.it) was chosen, because it is especially well suited photogrammetry and mapping. It is

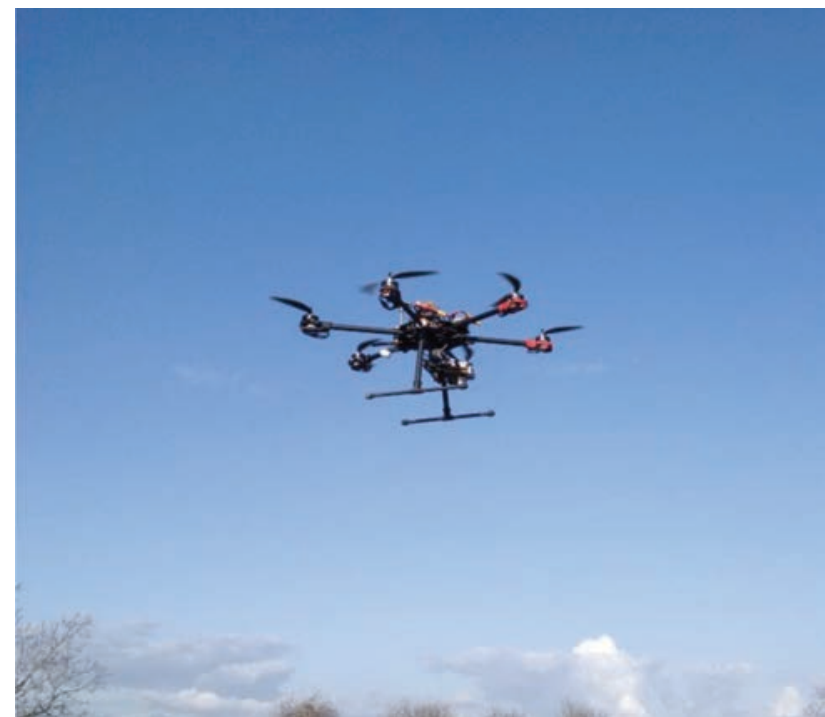

Fig. 1. The Tarot FY690s drone equipped with all essential hardware elements and software tools.

made of carbon fibre and can, even if the entire chassis weighs only $600 \mathrm{~g}$, support a shipment of $3 \mathrm{~kg}$. This drone was equipped with all essential equipment required for its control, programming and planning of the flight including a small digital camera for a variety of small-scale, aerial operations.

For photographic recording, we chose the $200 \mathrm{~g}$ Canon PowerShot S100 camera due to its high resolution (12.1 megapixels). It was equipped with a $7.44 \mathrm{x}$ $5.58 \mathrm{~mm}$ sensor with $5.2 \mathrm{~mm}$ focal length and built-in global positioning system (GPS) unit and raw image format. Properly made targets (Fig. 2) were used as ground control points (GCP) for post-processing purposes (Nex et al., 2013). The position of each target

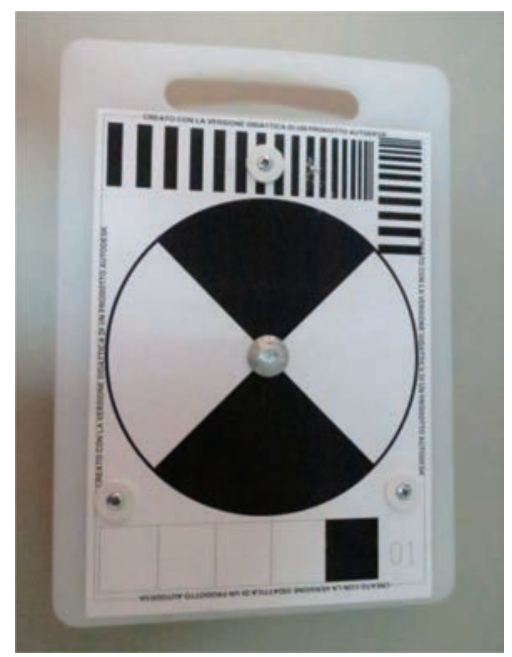

Fig. 2. Target with apposite support. 
was acquired using a Trimble Total Station geodimeter (http://www.trimble.com). Following analysis of the area of interest and the parameters of the on-board digital camera, the flight was programmed by applying dedicated software (Nex et al., 2013). In order to calculate the flight altitude, the camera focal lens was fixed at the required ground sample distance (GSD). The flight altitude is given according to Cannarozzo et al. (2012) by the equation:

$$
H=p \cdot N
$$

(equation 1)

where $H$ represents the altitude, $p$ the camera focal lens and $N$ the desired scale of image.

To minimize the influence of shadows on the ground and other effects reducing frame quality, flights were undertaken during the brightest hours and as far as possible in the absence of clouds, wind and haze. The modalities of flight execution ensures the longitudinal and transversal overlap of the frames taken (e.g. 60$80 \%$ ), while the global national satellite system (GNSS) and navigation system on-board the hexacopter guided and the improved image data acquisition. The metric reconstruction of the scene involved two preliminary steps: camera calibration and image orientation. We chose laboratory camera calibration versus in-flight calibration (Colomina et al., 2007) because it is more precise. The image orientation involved the extraction of tie points followed by photo alignment (Triggs et al., 2000; Gruen and Beyer, 2001) assisted by Agisoft Photoscan professional software (Agisoft LLC, St. Petersburg, Russia). To improve georeferencing and tie point extraction and minimize image block deformations as well as possible systematic errors, it was necessary to import a few GCPs in the alignment. Subsequently, the Agiscan software was applied to produce and process the polygonal model (mesh) needed to obtain geometrically corrected imaging (orthophotos) and accurate surface details (texture mapping) including DEM.

\section{Modelling of the transport process}

In order to delineate watersheds and overland flow paths, Jenson and Domingue (1988) suggest dividing the process into three steps: filling depressions obtained by the DEM, constructing the flow directions and finally creating a flow accumulation dataset. The DEM was converted to GRID format to make it more suitable for processing. This was done by interpolating the original points with the Kriging estimator using ArcGIS Software (ESRI; Redlands, CA, USA). Since raster cells can create discontinuities and drainage abnormalities in the hydro-graphic scenes due to absence of outlets (Infascelli et al., 2013), the first phase involves removing small DEM imperfections by identification and filling in these "pits" by means of the ArcGIS hydrology tool. The second step deals with the surface flow direction, a term that indicates which direction water will run out of a cell. When this concept is applied to a depression-less DEM, every cell assumes a particular flow direction because they all have a flow path. This step is carried out by applying the mono-directional, or eight-flow (D8) model, supported by the ArcGIS hydrology tool and flow-direction tool. The last phase, consists of using the ArcGIS flow-accumulation tool to create the flow accumulation dataset in which each cell is assigned a value equal to the number of cells that flow to it. This approach has been demonstrated to be particularly suitable for modelling the micro-rill network (Wolock et al., 1995; Beaujouan et al., 2001). The raster of accumulated flow created in each cell using the ArcGIS flow-accumulation tool made it possible to discover different micro-basins by applying various outlets. For each of them, the essential parameters for calculation of the TI and the CTI, such as local and downhill slope, drainage area, mean annual effective rainfall depth and evapotranspiration, were estimated.

\section{Suitable indices to predict wetlands distribution}

The several indices suited to predict wetlands distribution are given as follows. Firstly, the soil topographic index (STI) according to Beven et al. (1979) is given as:

$$
S T I=\ln \left(\frac{\alpha}{T \tan \beta}\right)
$$

(equation 2)

where $\alpha$ is the drainage area, $\beta$ the local slope and $T$ the trasmissivity. However, it has been shown that the value of the trasmissivity is usually less than the value of the area of drainage and the variation of the local slope, so it can be neglected. Therefore, the TI was introduced (Beven et al., 1979; Beven, 1986) as described by equation 3 :

$$
T I=\ln \left(\frac{\alpha}{\tan \beta}\right)
$$

(equation 3)

For any amount of rainfall, the TI value increases with the drainage basin and decreases with the slope. For this reason, Merot et al. (2003) introduced a more 
robust index, the clima-topographic index (CTI):

$$
C T I=\ln \left(\frac{V r}{\tan \beta}\right)
$$

(equation 4)

where $V r$ is the volume of effective annual rainfall, which is calculated by multiplying drainage area with the mean annual effective rainfall depth. Merot et al. (2003) determinated the mean annual effective rainfall as:

$$
\operatorname{Re} f f_{\text {annual }}=\sum_{1-12} \operatorname{Re} f f_{i}
$$

(equation 5)

where $\operatorname{Re} f f_{i}$ is the monthly effective rainfall depth, given by equation 6 below:

$$
\operatorname{Re} f f_{i}=\mathrm{R}_{i} P E T_{i}
$$

(equation 6)

$\operatorname{Re} f f_{i}=0$ when $R_{i} \leq P E T_{i}$.

We used expression 7 of the equations proposed by Hargreaves et al. (1985) since it was considered a good baseline for determining the potential evapotranspiration in Southern Italy (Pindozzi et al., 2013):

$$
P E T_{i}=0.0023 \times R_{a} \times\left(T_{\text {mean }}+17.8\right) \times \sqrt{\left(T_{\text {max }}-T_{\text {min }}\right)}
$$

(equation 7)

where $P E T_{i}\left(E T_{o}\right)$ is the potential evapotranspiration $P E T_{i}$ in $\mathrm{mm} \mathrm{day}^{-1}, R_{a}$ the extraterrestrial radiation in $\mathrm{MJ} \mathrm{x} \mathrm{m} \mathrm{m}^{-2} \mathrm{x}$ day $^{-1}$ (calculated by using methods reported in Allen et al. (1998)), the mean $\left(T_{\text {mean }}\right)$, maximum $\left(T_{\max }\right)$ and minimum $\left(T_{\min }\right)$, daily temperature in ${ }^{\circ} \mathrm{C}$, respectively.

In the calculation of the CTI, we used the downhill slope (the slope between the point of interest and the runoff course measured along the hydraulic path), since this improved the results, both from the technical (the local slope is smoothed with the downhill slope) and conceptual points of view (soil saturation depends not only on the up-slope factor but also on down-slope factors, not considered with TI) according to GascuelOdoux et al. (1998). It has been shown that this index is capable of predicting wetlands in a reliable manner without calibration in most cases (Merot et al., 2003) except for highly heterogeneous permeability soils that did not characterize the study area.

The CTI is more robust and realistic than TI according to Merot et al. (2003), but to evaluate it for the study area, it was necessary to know both the effective and mean annual rainfall, temperature and evapotranspiration data over the area basin and slope. Therefore, the precipitation records from neighbouring meteorological stations were analysed and used to compute the effective annual rainfall, the mean annual rainfall and evapotranspiration. We calculated both $T I$ and CTI in three micro-basins, which is required to detect heavy metal sedimentation points.

During data collection, the altitude of flight was fixed at a $25 \mathrm{~m}$ and the speed at $4 \mathrm{~m} \mathrm{x} \mathrm{s}^{-1}$. In this way, longitudinal and transversal overlap strips of $70 \%$ and $30 \%$, respectively, were ensured. Even if the coverage of the whole area could be obtained by the acquisition of 42 images, we preferred to take a pair of photos at each of the waypoint identified, totalling 84 images, in order to eliminate the possible blurry imagery during the reconstruction. These camera shots were taken during three different flight missions; the first two missions made up of 16 stages for a period of 12 minutes and the third characterized by 12 waypoints lasting for 8 minutes.

\section{Results}

A detailed orthophoto (Fig. 3) and a $0.03 \mathrm{~m}$ resolution DEM (Fig. 4) was generated by the block of images obtained. The flow direction, flow accumulation (relating to preferential paths of runoff water) and micro-basins rasters were generated by the microstream network. In particular, three watersheds were identified, represented by upper (red), middle (blue)
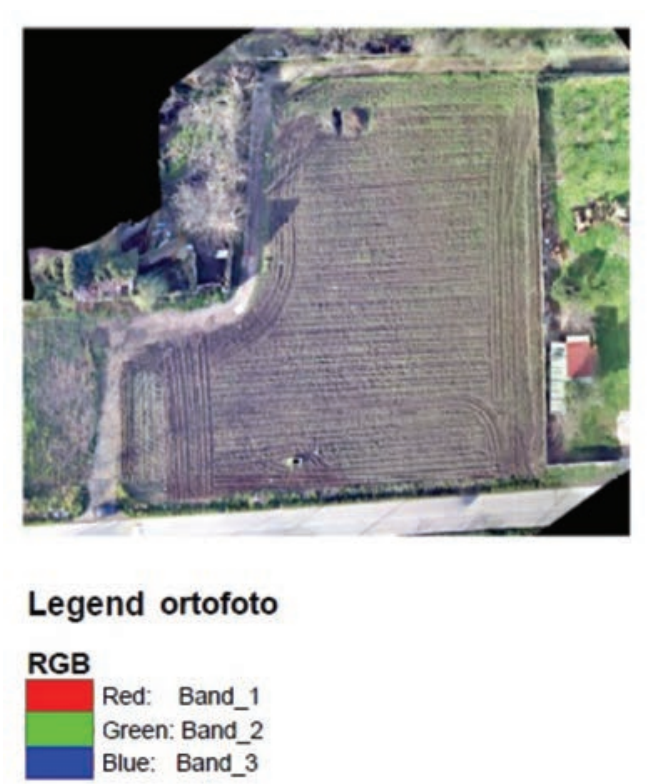

Fig. 3. Ortophoto of the study area. 


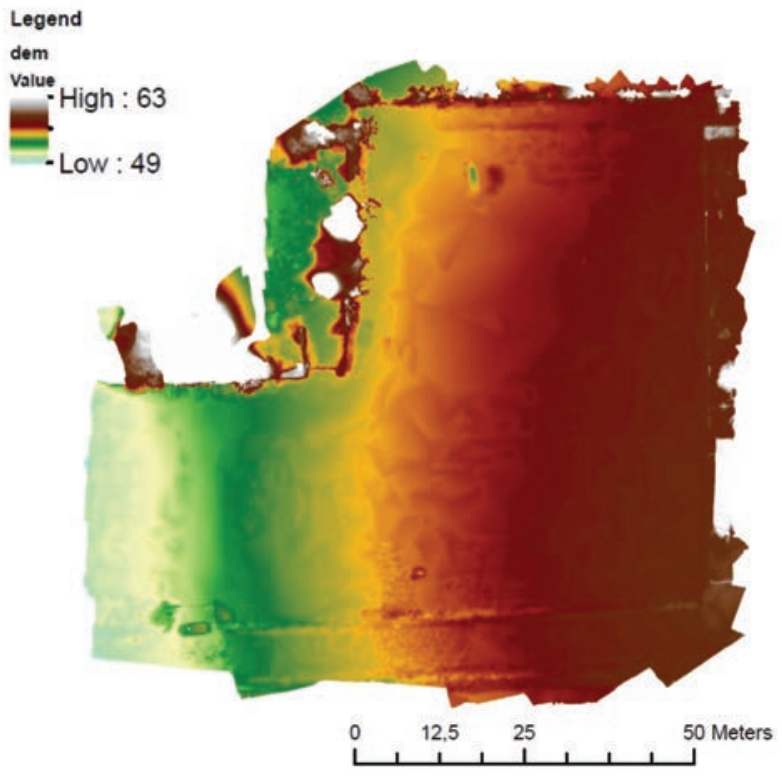

Fig. 4. Colour graph of the digital elevation model (DEM).

and bottom (green) micro-sections of the field, as shown in Fig. 5. These sections extend over an area $1,007.3 \mathrm{~m}^{2}, 1,050.1 \mathrm{~m}^{2}$ and $1,001.5 \mathrm{~m}^{2}$, respectively.

The average monthly rainfall equalled $78 \mathrm{~mm}$ between 1977 and 1993 with a peak of $137.4 \mathrm{~mm}$. The evapotranspiration in the same time interval showed a highest value $(157.1 \mathrm{~mm})$ in the month of July, while its lowest value $(27.2 \mathrm{~mm})$ was recorded in

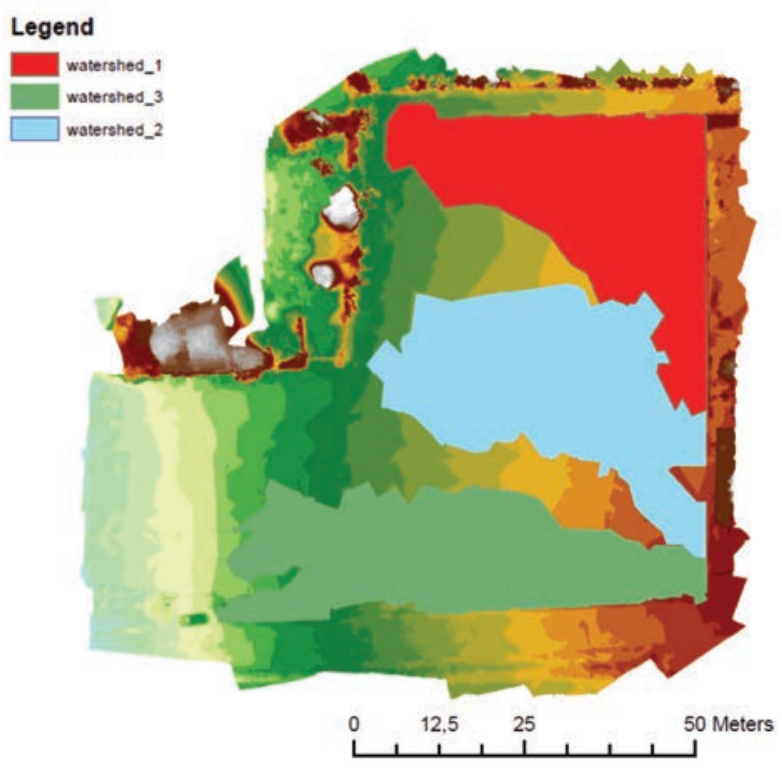

Fig. 5. Watersheds in the field investigated. Red $=$ the upper micro-basin $\left(1,007.3 \mathrm{~m}^{2}\right)$; blue = the watershed in the middle part $\left(1,050.1 \mathrm{~m}^{2}\right)$; green $=$ the micro-basin in the bottom part $\left(1,001.5 \mathrm{~m}^{2}\right)$. the month of January. The average values of the effective monthly rainfall showed a peak value equal to 77 $\mathrm{mm}$ in December and null in the warmer months from May to September. Thus, the effective average annual rainfall was estimated to be $27 \mathrm{~mm}$.

The TI and CTI were computed in the three study watersheds. As shown in Fig. 6, intervals of the TI values turned out to be different in the three sections of the map. The values were between 2.39 and 15.80, 0.99 and 15.84 , and -1.88 and 15.79 in the upper, middle and bottom areas, respectively. In addition, the CTI values (Fig. 7) were substantially different in each of the three zones. They varied between 2.47 and 18.21, 3.50 and 18.25 and 2.46 and 18.20 in the upper, middle and bottom parts of the field, respectively.

\section{Discussion}

Drones and the fifth-generation software for photogrammetry introduce many advantages to surface imaging. Indeed, the drone flight altitude has been drastically reduced allowing the capture of photos of very high resolution, while the time required for data acquisition and operating costs has fallen sharply (Nex et al., 2013). The coverage of the entire field under study here was achieved by a combination of just three missions resulting in a very moderate cost of the operation. The parallel processing of the 84 taken frames taken, made possible with the fifth-generation software, allowed us to obtain automatic restitution of DEM and to significantly decrease the time of analysis as shown by Pierrot-Deseilligny et al. (2011).

The micro runoff network, obtained from the analysis of the DEM, allowed the identification of three micro-basins, on which the TI and CTI could be calculated. The various slopes of the basins and the diverse drainage areas were strongly influenced by these values, and it was observed that the lower the value of the slope for a given area, the greater the value of $T I$. Since an increase in $T I$ is connected to a higher saturation of the soil, this index provides an important demonstration of the variability of soil moisture and the possibility that these areas correspond to sedimentation points. Thus, the CTI value varied in the upper, middle and bottom portion of the area of interest. Also in this case, the varying slope of the basins and the diversity of drainage areas influenced the differences in value. Due to its ability to correlate with the topographical features of the field and climatic events, the CTI seems to be the most robust index. For a given event area and rainfall, CTI is mainly influenced by the slope, as this index increases with 

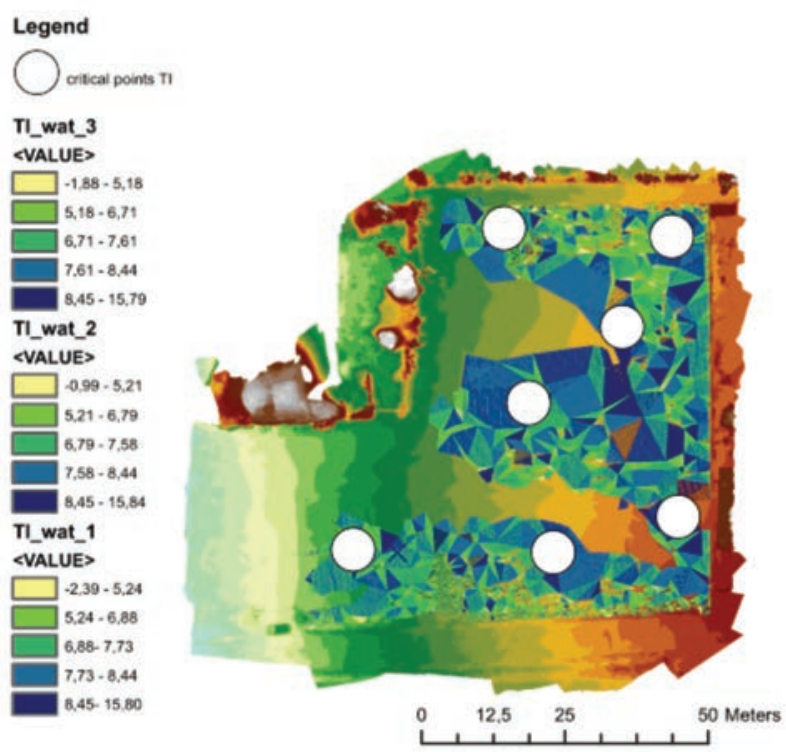

Fig. 6. Variation of the range of the topographic index (TI). Upper micro-basin $=-2.39$ and 15.80; Middle of the field $=$ -0.99 and 15.84; Bottom of the field $=-1.88$ and 15.79. The white circles represent sampling areas.

reduction of slope, increase of the drainage area and intensive, effective rain. Therefore, as in the previous case, water accumulates particularly in flat areas with a consequent increase in the degree of saturation. It can therfore be hypothesized that these zones correspond to the heavy metal sedimentation points.

The reasons why the values of the two indices differ can be deduced from the above discussion. We feel

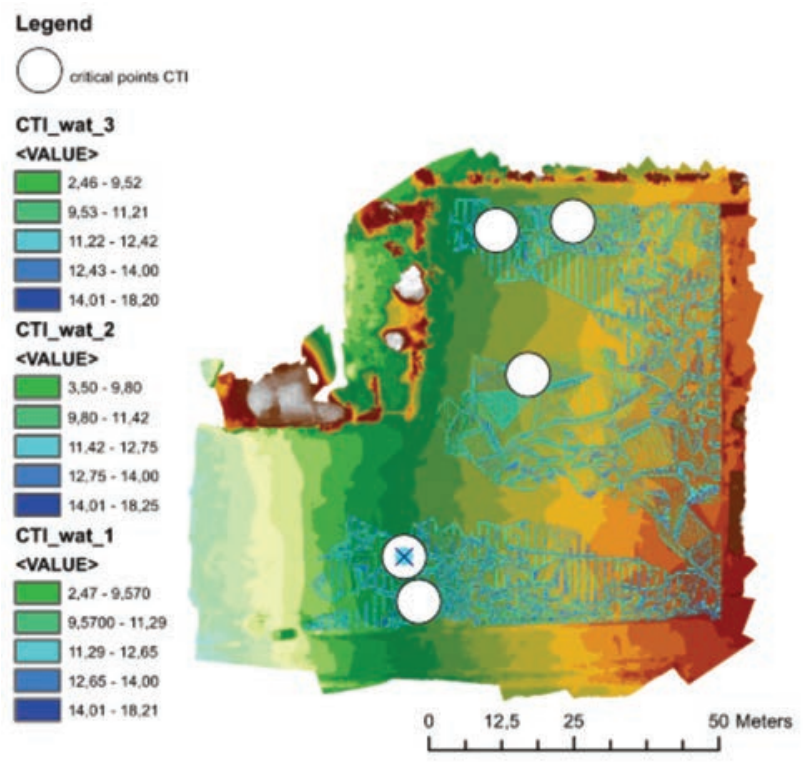

Fig. 7. Variation of the range of the clima-topographic index (CTI). Upper micro-basin $=2.47$ and 18.21 ; middle of the field $=3.50$ and 18.25 ; bottom of the field $=2.46$ and 18.20 that the CTI is a more robust index than TI due to the replacement of slope with effective rainfall, which improves the results as shown by Gascuel-Odoux et al. (1998). As a matter of fact, the local slope substitution with the downhill element led us to take into account both down-slope and up-slope. Moreover, it has been shown that CTI has the higher potential for determining the position and the general extent of wetlands in a reliable manner, even if it decreases when the soil has a highly heterogeneous permeability (Merot et al., 2003). In addition, maximum TI values extend over larger areas than the CTI, while the minimum values almost coincide. Consequently, the CTI allows the identification of the areas to be sampled more clearly. For these reasons, we propose that the CTI is better suited for the identification of sedimentation points for heavy metals.

\section{Conclusions}

In this study, we introduced an innovative methodology for predicting the accumulation zones of substances that can disperse through aquifers. This approach looks promising because it reduces the cost of soil sampling by making it sufficient to take samples only from the points of maximum CTI (or TI) to determinate the sedimentation points of heavy metals. Indeed, these reasons motivated us to apply this model in the Campania region in Italy, since it is characterized by a complex and difficult environmental situation.

\section{Acknowledgements}

This study was financed by the Life Ecoremed Project (LIFE11/ENV/IT/275) and by the ENERBIOCHEM Project (PON 01_01966).

\section{References}

Albanese S, Cicchella D, 2012. Legacy problems in urban geochemistry. Elements 8, 423-428.

Albanese S, De Vivo B, Lima A, Cicchella D, 2007. Geochemical background and baseline values of toxic elements in stream sediments of Campania region (Italy). J Geochem Explor 93, 21-34.

Beaujouan V, Durand P, Ruiz L, 2001. Modelling the effect of the spatial distribution of agricultural practices on nitrogen fluxes in rural catchments. Ecol Modell 137, 93-105.

Beven K, 1986. Runoff production and flood frequency in catchments of order n: an alternative approach. Scale problem in hydrology. Water Trans 6, 107-131.

Beven KJ, Kirkby MJ, 1979. A physically based, variable con- 
tributing area model to basin hydrology. Hydrol Sci B 24, 43-69.

Bishop MP, James LA, Shroder Jr JF, Walsh SJ, 2012. Geospatial technologies and digital geomorphological mapping: Concepts, issues and research. Geomorphology, 137, 5-26.

Cannarozzo R, Cucchiarini L, Meschieri W, 2012. La presa dei fotogrammi. In: Misure, Rilievo, Progetto. Zanichelli Editore. Bologna, 34-66 pp.

Cicchella D, De Vivo B, Lima A, 2005. Background and baseline concentration values of elements harmful to human health in the volcanic soils of the metropolitan and provincial areas of Napoli (Italy). Geochem-Explor Env A 5, 29-40.

Colomina I, Blàzquez M, Molina P, Parès ME, Wis M, 2008. Towards a new paradigm for high resolution low-cost photogrammetry and remote sensing. Int. Archives of Photogrammetry, Remote sensing and Spatial information Scieces, Beijing, China 37, 1201-1206.

Dặguţ L, Eisank C, 2011. Object representations at multiple scales from digital elevation models. Geomorphology, 129, 183-189.

De Roeck E, Van Coillie F, De Wulf R, Soenen K, Charlier J, Vercruysse J, Hantson W, Ducheyne E, Hendrickx G, 2014. Fine-scale mapping of vector habitats using very high resolution satellite imagery: a case-study on liver fluke. Geospat Health, 8, S671-S683.

De Vivo B, Lima A, Albanese S, 2012. Atlante geochimico ambientale del SIN (Sito di Interesse Nazionale) litorale Domizio Flegreo e Agro Aversano. Ariccia (RM): Aracne editrice.

De Vivo B, Torok K, Ayuso R A, Lima A, Lirer L, 1995. Fluid inclusion evidence for magmatic silicate/saline/C02 immicibility and geochemistry of alkaline xenoliths from Ventotene island (Italy). Geochim Cosmochim Acta 59, 2941-2953.

Dehn M, Gärtner H, Dikau R, 2001. Principles of semantic modeling of landform structures. Comput Geosci 27, 1005-1010.

Dent D, Young A, 1981. Soil survey and land evaluation. London: George Allen and Unwin, 278 pp.

European Union, 2002. Heavy metals in wastes. European Commission on Environment. Available at: http://ec.europa.eu/environment/waste/studies/pdf/heavymetalsreport.pdf (accessed on June 2013).

Evans IS, 1977. World-wide variations in the direction and concentration of cirque and glacier aspects. Geogr Ann A 59, 151175.

Evans IS, 2012. Geomorphometry and landform mapping: what is a landform? Geomorphology, 137, 94-106.

Filippelli G, Morrison M, Cicchela D, 2012. Urban geochemistry and human health. Elements 8, 439-444.

Florinsky IV, 1998. Combined analysis of digital terrain models and remotely sensed data in landscape investigations. Prog Phys Geogr 22, 28.

Gascuel-Odoux C, Merot P, Crave A, Gineste P, Taha A, Zhang Z, 1998. Les zones contributives de fond de vallée: localisation, structure et fonctionnement hydrodynamique.
Agriculture intensive et qualité des eaux, Coll Sciences Update, éd INRA 129-141.

Gold DP, Parizek R R, Alexander SA, 1973. Analysis and application of ERTS-1 data for regional geological mapping. Proceedings of the first symposium of significant results obtained from the earth resources technology satellite-1, NASA, 231-246 pp.

Gruen A, Beyer HA, 2001. System calibration through self calibration. In: Calibration and orientation of cameras in computer vision. Gruen A, Huang TS (eds). New York: Springer, 163$194 \mathrm{pp}$.

Hooke JM, Horton BP, Moore J, Taylor MP, 1994. Upper river Severn (Caersws) channel study. Report to the Countryside Council for Wales, University of Portsmouth, 165 pp.

Hugenholtz $\mathrm{CH}$, Whitehead $\mathrm{K}$, Brown OW, Barchyn TE, Moorman BJ, LeClair A, Riddell K, Hamilton T, 2013. Geomorphological mapping with a small unmanned aircraft system (sUAS): feature detection and accuracy assessment of a photogrammetrically-derived digital terrain model. Geomorphology 194, 16-24.

Infascelli R, Faugno S, Pindozzi S, Boccia L, Merot P, 2013. Testing different topographic indexes to predict wetlands distribution. Proc Environ Sci 19, 733-746.

Jarup L, 2003. Hazards of heavy metal contamination. Brit Med Bull 68, 167-182.

Jenson SK, Domingue JO, 1988. Extracting topographic structure from digital elevation data for geographic information system analysis. Photogramm Eng Rem S 54, 1593-1600.

Lăcătuşu R, Răuţă C, Cârstea S, Ghelase I, 1996. Soil-plant-man relationships in heavy metal polluted areas in Romania. Appl Geochem 11, 105-107.

Lejot J, Delacourt C, Piégay H, Fournier T, Trémélo ML, Allemand P, 2007. Very high spatial resolution imagery for channel bathymetry and topography from an unmanned mapping controlled platform. Earth Surf Proc Land 32, 17051725.

McCluggage D, 1991. Heavy metal poisoning. NCS Magazine. The Bird Hospital, CO, USA. Available at: www.cockatiels.org/articles/Diseases/metals.html (accessed on June 2013).

Merot P, Squividant H, Aurousseau P, Hefting M, Burt T, Maitre V, Kruk M, Butturini A, Thenail C, Viaud V, 2003. Testing a climato-topographic index for predicting wetlands distribution along an European climate gradient. Ecol Modell 63, 51-71.

Minàr J, Evans IS, 2008. Elementary form for land surface segmentation: the theoretical basis of terrain analysis and geomorphological mapping. Geomorphology 95, 236-259.

Montreuil O, 2011. Relation entre l'ordre des bassins versants, l'organisation spatiale et le fonctionnement hydrologique et hydrochimique des zones humides riveraines. Géosciences Rennes 1, 28. 
Moore AB, Morris KP, Blackwell GK, Jones AR, Sims PC, 2003. Using geomorphological rules to classify photogrammetrically-derived digital elevation models. Int J Remote Sens 24, 2613-2626.

Muchuweti M, Birkett JW, Chinyanga E, Zvauya R, Scrimshaw MD, Lester JN, 2006. Heavy metal content of vegetables irrigated with mixture of wastewater and sewage sludge in Zimbabwe: implications for human health. Agr Ecosyst Environ 112, 41-48.

Mulder VL, Bruina S, Schaepmana ME, Mayr TR, 2010. The use of remote sensing in soil and terrain mapping: a review. Geoderma 162, 1-2.

Nex F, Remondino F, 2013. UAV for 3D mapping applications: a review. Applied Geomatics 6, 1-15.

Oliver MA, 1997. Soil and human health: a review. Eur J Soil Sci 48, 573-592.

Ollesch G, Kistner I, Meissner R, Lindenschmid KE, 2006. Modelling of snowmelt erosion and sediment yield in a small low-mountain catchment in Germany. Catena 68, 161-176.

Pierrot-Deseilligny M, De Luca L, Remondino F, 2011. Automated image - based procedures for accurate artifacts 3D modeling and orthoimage generation. Prague: Czech Republic, Geoinformatics FCE CTU Journal 6, 291-299.
Pindozzi S, Faugno S, Okello C, Boccia L, 2012. Experimental evaluation of manure evaporation in the paddock for a management algorithm development. Proceedings of international conference of agricultural conference, 8-12 July 2012, Valencia Conference Center, Valencia, Spain.

Pindozzi S, Faugno S, Okello C, Boccia L, 2013. Measurement and prediction of buffalo manure evaporation in the farmyard to improve farm management. Biosyst Eng 115, 117-124.

Swaine DJ, 1962. The trace element content of fertilizers. Soil Sci 94, 134.

Triggs W, McLauchlan P, Hartley R, Fitzgibbon A, 2000. Bundle adjustment - A modern synthesis. In: Vision Algorithms: Theory and Practice. Triggs W, Ziesserman A, Sterliski R (eds). Berlin: Springer Verlag, 298-375 pp.

Vito M, Merola G, Giordano A, Ragone G, 2009. Relazione sullo stato dell'ambiente in Campania 2009. Chapter 12, 327 349 pp. Avaible at http://www.arpacampania.it/documents/30626/52179/7_RSA+2009.pdf (accessed on June 2013).

Wolock DM, McCabe GJ, 1995. Comparison of single and multiple flow direction algorithms for computing topographic parameters in TOPMODEL. Water Resour Res 31, 13151324. 